\title{
Synthesis and Crystal Structure of the First Example of a Tris-Chelated Co(II) Complex Based on Oxamide Dioxime Ligand
}

\author{
Gouet Bebga1, Emmanuel N. Nfor'2, Yves A. Mbiangué3 ${ }^{3}$ Patrick L. Djonwouo4, \\ Justin Nenwa ${ }^{*}$ \\ ${ }^{1}$ Department of Chemistry, Higher Teachers Training College, University of Yaounde 1, Yaounde, Cameroon \\ ${ }^{2}$ Department of Chemistry, University of Buea, Buea, Cameroon \\ ${ }^{3}$ Department of Chemistry, Higher Teachers Training College, University of Maroua, Maroua, Cameroon \\ ${ }^{4}$ Department of Inorganic Chemistry, Coordination Chemistry Laboratory, University of Yaounde 1, Yaounde, \\ Cameroon \\ Email: "inenwa@yahoo.fr
}

Received 29 January 2015; accepted 10 May 2015; published 14 May 2015

Copyright (C) 2015 by authors and Scientific Research Publishing Inc.

This work is licensed under the Creative Commons Attribution International License (CC BY).

http://creativecommons.org/licenses/by/4.0/

c) (i)

\begin{abstract}
A new cobalt(II) complex, [ $\left.\mathrm{Co}\left(\mathrm{H}_{2} \mathrm{Oxado}\right)_{3}\right] \mathrm{C}_{2} \mathrm{O}_{4} \cdot \mathrm{H}_{2} \mathrm{Oxado} \cdot 2 \mathrm{H}_{2} \mathrm{O}\left(\mathrm{H}_{2} \mathrm{oxado}=\right.$ oxamide dioxime $)$, has been synthesized in aqueous solution and characterized by elemental analysis and single crystal $X$-ray structure determination. The complex crystallizes in the triclinic space group $P$-1, with the parameters $a=9.46(4), b=11.84(5), c=12.81(5) \AA, \alpha=104.94(6), \beta=99.29(5), \gamma=106.73(5), V=$ 1284(9) $\AA^{3}, Z=2$. The central cobalt(II) cation is pseudo-octahedrally coordinated by six imino $N$ atoms of the neutral oxamide dioxime ligand. In the solid state, each of the following bricks, namely the cationic complexes, the oxalate dianions as well as the oxamide dioxime crystallization molecules, pile up parallel to the $a$ axis. The bulk structure is consolidated by an extended three-dimensional network of hydrogen bridgings-that link the ionic partners, oxamide dioxime and water molecules to one another-and by coulombic interactions.
\end{abstract}

\section{Keywords}

Crystal Structure, Cobalt(II) Complex, Oxamide Dioxime, Oxalate, Hydrogen Bridging

\section{Introduction}

Transition metal complex cations of the form $\left[\mathrm{M}\left(\mathrm{H}_{2} \mathrm{Oxado}\right)_{3}\right]^{\mathrm{n}+}\left(\mathrm{M}=\right.$ metal(II) or metal(III), $\mathrm{n}=2$ or $3, \mathrm{H}_{2} \mathrm{Oxado}=$

${ }^{*}$ Corresponding author.

How to cite this paper: Bebga, G., Nfor, E.N., Mbiangué, Y.A., Djonwouo, P.L. and Nenwa, J. (2015) Synthesis and Crystal Structure of the First Example of a Tris-Chelated Co(II) Complex Based on Oxamide Dioxime Ligand. Crystal Structure Theory and Applications, 4, 9-15. http://dx.doi.org/10.4236/csta.2015.42002 
oxamide dioxime), constitute an interesting family of chiral and—eventually—paramagnetic cations, due to their molecular structure (geometry and volume) that predestines them to undergo straightforward chemical combinations with suitable anionic counterparts such as the oxalatometalate series, $\left[\mathrm{M}^{\prime}\left(\mathrm{C}_{2} \mathrm{O}_{4}\right)_{3}\right]^{3-}\left(\mathrm{M}^{\prime}=\right.$ metal(III)), thus generating a wide range of multifunctional crystalline materials [1] required in the development of emerging technologies [2]-[5]. It has been observed previously that in aqueous solution, the $\mathrm{Co}^{\mathrm{II}}$ ion generally reacts with the oxamide dioxime ligand, yielding the familiar trischelated $\mathrm{Co}^{\mathrm{III}}$ complex cation, $\left[\mathrm{Co}\left(\mathrm{H}_{2} \mathrm{Oxado}\right)_{3}\right]^{3+}[6]-[8]$. In our current research program which is focused on fabricating multifunctional materials involving $\mathrm{N}, \mathrm{N}^{\prime}-$ or O,O'chelating ligands, the $\left[\mathrm{Co}\left(\mathrm{H}_{2} \mathrm{Oxado}\right)_{3}\right]^{3+}$ building block and its homologous nickel(II) complex, $\left[\mathrm{Ni}\left(\mathrm{H}_{2} \mathrm{Oxado}\right)_{3}\right]^{2+}$, have proven to be good partners in the formation of hydrogen-bonded functional solid-state assemblies [9] [10].

Along the line of this research program, an attempt to prepare the elusive tris(oxamide dioxime)cobalt(III) tris(oxalato)cobaltate(III), [Co( $\mathrm{H}_{2}$ oxado $\left.)_{3}\right]\left[\mathrm{Co}\left(\mathrm{C}_{2} \mathrm{O}_{4}\right)_{3}\right] \cdot \mathrm{nH}_{2} \mathrm{O}$, similar to $\left[\mathrm{Co}\left(\mathrm{H}_{2} \text { oxado }\right)_{3}\right]\left[\mathrm{Cr}_{2}\left(\mathrm{C}_{2} \mathrm{O}_{4}\right)_{3}\right] \cdot 5 \mathrm{H}_{2} \mathrm{O}$ [9] led to the serendipitous isolation of the cobalt(II) title compound, $\left[\mathrm{Co}\left(\mathrm{H}_{2} \mathrm{Oxado}\right)_{3}\right] \mathrm{C}_{2} \mathrm{O}_{4} \cdot \mathrm{H}_{2} \mathrm{Oxado} \cdot 2 \mathrm{H}_{2} \mathrm{O}$, the structure of which is reported herein. The present finding turns out to be quite interesting, in as much as it provides, to the best of our knowledge, the first example of a complex salt containing the dipositive $\left[\mathrm{Co}\left(\mathrm{H}_{2} \mathrm{Oxado}\right)_{3}\right]^{2+} \mathrm{ca}-$ tion, as highlighted in Scheme 1.

\section{Experimental}

\subsection{Materials and Measurements}

The organic ligand $\mathrm{H}_{2}$ oxado (analytical grade) was freshly prepared by the condensation of dithiooxamide (98.5\%, Fluka) and hydroxylammonium chloride (99\%, Merck) in presence of sodium carbonate $(99.5 \%$, Prolabo) as previously reported [9] [11]. The tripotassium tris(oxalato)cobaltate(III) trihydrate salt, $\mathrm{K}_{3}\left[\mathrm{Co}\left(\mathrm{C}_{2} \mathrm{O}_{4}\right)_{3}\right] \cdot 3 \mathrm{H}_{2} \mathrm{O}$, was synthesized as described by Bailar \& Jones [12]. All other chemicals were purchased and used as received. Elemental analysis was performed on a VARIO EL (Heraeus) CHNS analyzer.

\subsection{Synthesis of $\left[\mathrm{Co}\left(\mathrm{H}_{2} \text { oxado }\right)_{3}\right] \mathrm{C}_{2} \mathrm{O}_{4} \cdot \mathrm{H}_{2}$ oxado: $2 \mathrm{H}_{2} \mathrm{O}$}

The title compound was obtained as follows: dark green crystals of $\mathrm{K}_{3}\left[\mathrm{Co}\left(\mathrm{C}_{2} \mathrm{O}_{4}\right)_{3}\right] \cdot 3 \mathrm{H}_{2} \mathrm{O}(0.5 \mathrm{~g}, 1 \mathrm{mmol})$ were dissolved in $\mathrm{H}_{2} \mathrm{O}(50 \mathrm{~mL})$ acidified with a drop of $\mathrm{HNO}_{3}$. To the filtered solution were added with stirring at $30^{\circ} \mathrm{C}$ successive small portions of oxamide dioxime $(0.36 \mathrm{~g}, 3 \mathrm{mmol})$, followed by portions of finely powdered $\mathrm{Co}\left(\mathrm{NO}_{3}\right)_{2} \cdot 6 \mathrm{H}_{2} \mathrm{O}(0.3 \mathrm{~g}, 1 \mathrm{mmol})$. The reaction mixture was stirred magnetically for $1 \mathrm{~h}$ and allowed to decant over $2 \mathrm{~h}$. The reddish-pink precipitate of $\mathrm{CoC}_{2} \mathrm{O}_{4}$ was carefully filtered off, and the solution left to evaporate slowly in a hood at room temperature. After two weeks, prismatic reddish crystals suitable for single crystal X-ray studies were harvested. Anal. Calcd. for $\mathrm{C}_{10} \mathrm{H}_{28} \mathrm{CoN}_{16} \mathrm{O}_{14}$ : C, 18.33; H, 4.30; N, 34.20\%. Found: C, 18.32; $\mathrm{H}, 4.30$; N, 34.18\%.

\subsection{Crystal Structure Determination and Refinement}

A suitable single crystal of the title compound with dimensions $0.5 \times 0.12 \times 0.10 \mathrm{~mm}$ was mounted on a glass

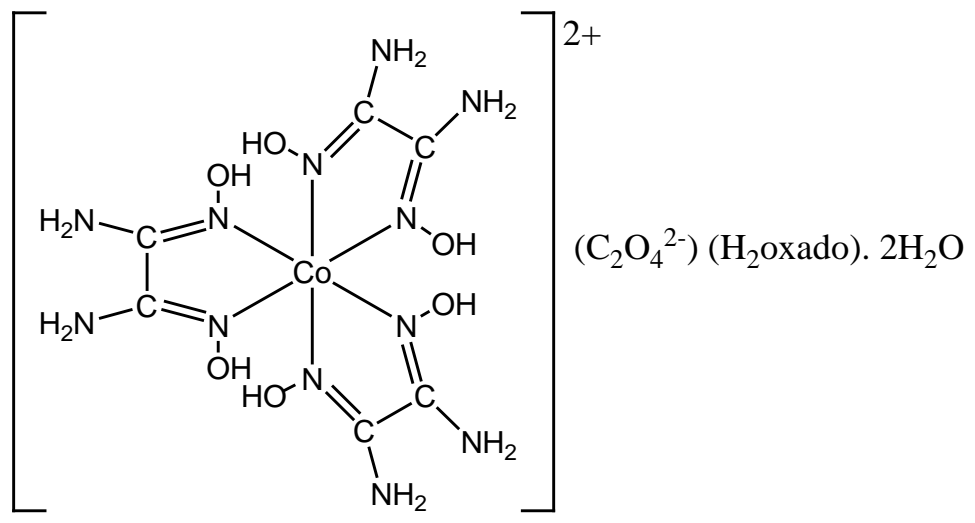

Scheme 1. Chemical diagram of the title compound. 
fiber and fixed to the goniometer head. Data collection [13] was carried out on a Bruker-Nonius X8 kappa APEX II CCD area-detector diffractometer using graphite-monochromatic radiation $\lambda(\mathrm{Mo} \mathrm{K \alpha})=0.71073 \AA$ at 296(2) K. Data reduction was performed using SAINT [13], and absorption corrections were carried out by multi-scan method by SADABS [14]. The structure was solved by direct methods and refined against $\mathrm{F}^{2}$ by full-matrix least-squares techniques with SHELXTL [15]. All non-hydrogen atoms were refined with anisotropic displacement parameters. The hydrogen atoms were included from calculated positions and refined riding on their respective parent atoms with isotropic displacement parameters. Crystal data and structure refinement details for the title compound are summarized in Table 1, and selected bond lengths and angles in Table 2.

\section{Results and Discussion}

Single-crystal X-ray structural analysis reveals that the title compound crystallizes in the triclinic space group $P$-1. It is formulated $\left[\mathrm{Co}\left(\mathrm{H}_{2} \text { oxado }\right)_{3}\right] \mathrm{C}_{2} \mathrm{O}_{4} \cdot \mathrm{H}_{2}$ oxado $\cdot 2 \mathrm{H}_{2} \mathrm{O}$. As shown in Figure 1, the molecular structure is composed of one $\left[\mathrm{Co}\left(\mathrm{H}_{2} \mathrm{Oxado}\right)_{3}\right]^{2+}$ complex cation, one oxalate (2-) anion, one oxamide dioxime molecule and two solvent water molecules. The point of prime interest in this report is the assessment of the existence of the pseudo-octahedral complex cation, tris(oxamide dioxime)cobalt(II), $\left[\mathrm{Co}\left(\mathrm{H}_{2} \mathrm{Oxado}\right)_{3}\right]^{2+}$, and this, as far as we know, is raised here for the first time. The oxamide dioxime acting as a crystallization molecule has been described previously [16]. Selected bond lengths and angles of the title compound are listed in Table 2, and compared with the corresponding values (in brackets) for the reported $\left[\mathrm{Co}\left(\mathrm{H}_{2} \mathrm{Oxado}\right)_{3}\right]^{3+}$ cation [6]-[8]. Data derived from this tripostive cation reflect nicely the $C 3$ symmetry of the complex entity, whereas those derived from the dipositive complex cation, $\left[\mathrm{Co}\left(\mathrm{H}_{2} \mathrm{Oxado}\right)_{3}\right]^{2+}$, deviate noticeably from this symmetry. However, the pseudo-octahedral coordination of the central cobalt and the chiral nature of the complex cation are maintained. Whereas the O-N bond lengths within the $\left[\mathrm{Co}\left(\mathrm{H}_{2} \text { oxado }\right)_{3}\right]^{2+}$ entities of the present structure range from 1.290(3) to 1.490 (2) $\AA$, its average value $(1.383 \AA)$ is slightly shorter than $\mathrm{O}-\mathrm{N}$ bonds in the familiar $\left[\mathrm{Co}\left(\mathrm{H}_{2} \mathrm{Oxado}\right)_{3}\right]^{3+}$ cation whose common value is 1.391(6) $\AA$ (Table 2). The projection of the structure along [100] highlights the $\left[\mathrm{Co}\left(\mathrm{H}_{2} \mathrm{Oxado}\right)_{3}\right]^{2+}$ ions disposed in centrosymmetric dimers leading to a zig-zag chain running along $c$ axis (Figure 2). The threedimensional crystal packing of the title compound is reinforced by extended $\mathrm{O}-\mathrm{H} \cdots \mathrm{O}, \mathrm{O}-\mathrm{H} \cdots \mathrm{N}$ and $\mathrm{N}-\mathrm{H} \cdots \mathrm{O}$ bridges which interlink the complex cations, $\left[\mathrm{Co}\left(\mathrm{H}_{2} \mathrm{Oxado}\right)_{3}\right]^{2+}$, oxalate anions, oxamide dioxime molecules and water molecules.
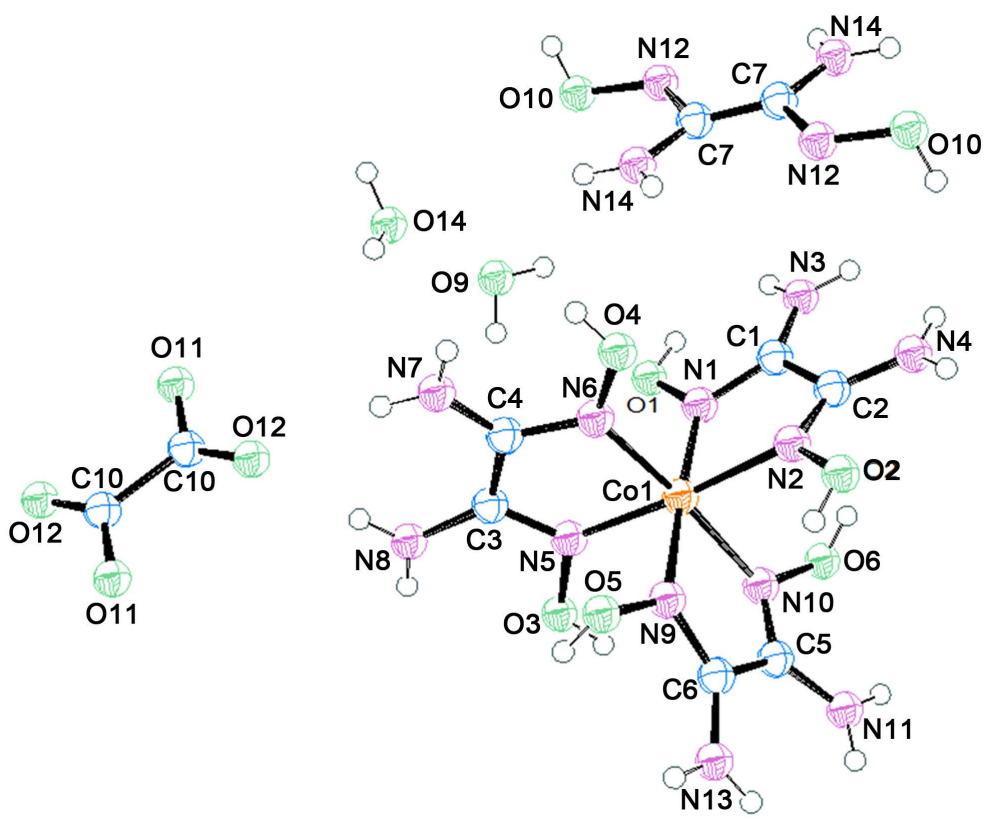

Figure 1. An ORTEP drawing of $\left[\mathrm{Co}\left(\mathrm{H}_{2} \mathrm{Oxado}\right)_{3}\right] \mathrm{C}_{2} \mathrm{O}_{4} \cdot \mathrm{H}_{2}$ oxado $\cdot 2 \mathrm{H}_{2} \mathrm{O}$ showing atom-labelling scheme with displacement ellipsoids drawn at $50 \%$ probability level. 
Table 1. Crystal data and structure refinement details for the title compound.

\begin{tabular}{|c|c|}
\hline $\mathrm{CCDC} \mathrm{N}^{\circ}$ & CCDC-839359 \\
\hline Empirical formula & $\mathrm{C}_{10} \mathrm{H}_{28} \mathrm{CoN}_{16} \mathrm{O}_{14}$ \\
\hline Formula weight & 655.42 \\
\hline Temperature (K) & $296(2)$ \\
\hline Wavelength $(\AA)$ & 0.71073 \\
\hline Crystal system & triclinic \\
\hline Space group & $P-1$ \\
\hline \multicolumn{2}{|l|}{ Unit cell dimensions } \\
\hline$a(\AA)$ & $9.46(4)$ \\
\hline$b(\AA)$ & $11.84(5)$ \\
\hline$c(\AA)$ & $12.81(5)$ \\
\hline$\alpha\left(^{\circ}\right)$ & $104.94(6)$ \\
\hline$\beta\left(^{\circ}\right)$ & $99.29(5)$ \\
\hline$\gamma\left(\left(^{\circ}\right)\right.$ & $106.73(5)$ \\
\hline Volume $\left(\AA^{3}\right)$ & $1284(9)$ \\
\hline$Z$ & 2 \\
\hline Density (calculated, $\mathrm{g} \cdot \mathrm{cm}^{-3}$ ) & 1.696 \\
\hline Absorption coefficient $\left(\mathrm{mm}^{-1}\right)$ & 0.765 \\
\hline$F(000)$ & 678 \\
\hline Crystal size (mm) & $0.50 \times 0.12 \times 0.10$ \\
\hline Theta range for data collection $\left({ }^{\circ}\right)$ & $1.70-25.00$ \\
\hline Limiting indices & $\begin{array}{c}-11 \leq h \leq 11 \\
-14 \leq k \leq 8 \\
-15 \leq l \leq 15\end{array}$ \\
\hline Reflections collected & 6152 \\
\hline Independent reflections & $4429[R($ int $)=0.1281]$ \\
\hline Absorption correction & Semi-empirical from equivalents \\
\hline Refinement method & Full-matrix least-squares on $F^{2}$ \\
\hline Data/restraints/parameters & $4429 / 0 / 379$ \\
\hline Goodness-of-fit on $F^{2}$ & 1.008 \\
\hline Final $R$ indices $[I>2 \sigma(I)]$ & $R_{1}=0.0324, \mathrm{w} R_{2}=0.0657$ \\
\hline$R$ indices (all data) & $R_{1}=0.0379, \mathrm{w} R_{2}=0.0685$ \\
\hline Largest difference peak and hole $\left(\mathrm{e} \AA^{-3}\right)$ & 4.812 and -3.307 \\
\hline Extinction coefficient & $0.000(9)$ \\
\hline Completeness to $\theta=25.00, \%$ & 97.9 \\
\hline
\end{tabular}




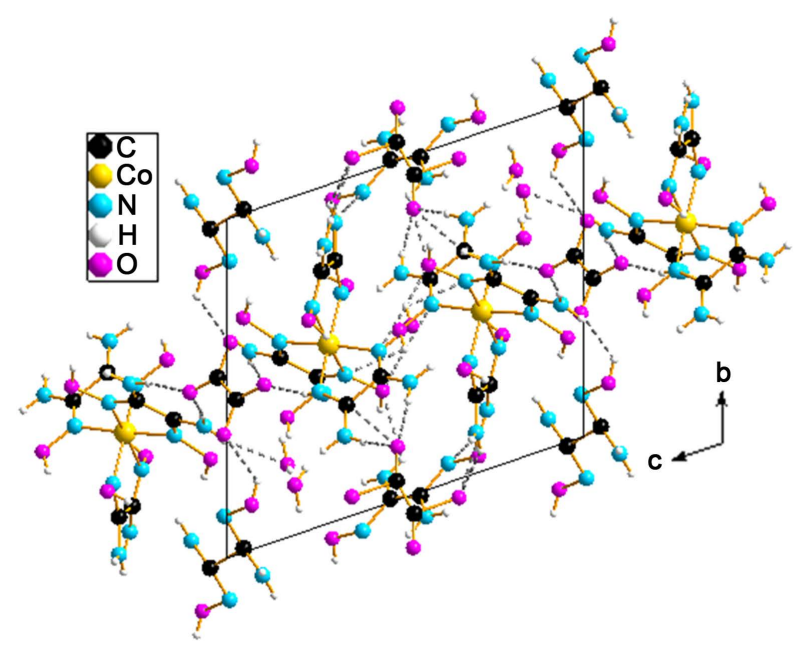

Figure 2. Projection of the achiral unit cell of the title compound along [100], showing centro-symmetric dimerization of $\mathrm{Co}^{\mathrm{II}}$ complex cations and interconnection of these dimers, $\mathrm{C}_{2} \mathrm{O}_{4}{ }^{2-}$ dianions, $\mathrm{H}_{2}$ oxado and $\mathrm{H}_{2} \mathrm{O}$ molecules via hydrogen bridges (dotted lines).

Table 2. Selected bond lengths ( $\AA$ ) and angles ( ${ }^{\circ}$ ) for the title compound*.

\begin{tabular}{|c|c|c|}
\hline $\mathrm{Co}(1)-\mathrm{N}(1)$ & $1.850(3)$ & {$[1.910(4)]$} \\
\hline $\mathrm{Co}(1)-\mathrm{N}(5)$ & $1.939(2)$ & [1.910 (5)] \\
\hline $\mathrm{Co}(1)-\mathrm{N}(6)$ & $1.953(2)$ & [1.910 (4)] \\
\hline $\mathrm{Co}(1)-\mathrm{N}(2)$ & $1.952(2)$ & [1.910 (4)] \\
\hline $\mathrm{Co}(1)-\mathrm{N}(9)$ & $1.962(2)$ & [1.910 (4)] \\
\hline $\mathrm{Co}(1)-\mathrm{N}(10)$ & $2.020(2)$ & [1.910 (5)] \\
\hline $\mathrm{O}(1)-\mathrm{N}(1)$ & $1.370(3)$ & [1.391 (6)] \\
\hline $\mathrm{O}(2)-\mathrm{N}(2)$ & 1.390 (3) & [1.391 (6)] \\
\hline $\mathrm{O}(3)-\mathrm{N}(5)$ & $1.490(2)$ & [1.391 (6)] \\
\hline $\mathrm{O}(4)-\mathrm{N}(6)$ & $1.380(2)$ & [1.391 (6)] \\
\hline $\mathrm{O}(5)-\mathrm{N}(9)$ & $1.290(3)$ & [1.391 (6)] \\
\hline $\mathrm{O}(6)-\mathrm{N}(10)$ & $1.380(2)$ & [1.391 (6)] \\
\hline $\mathrm{N}(1)-\mathrm{Co}(1)-\mathrm{N}(6)$ & $89.8(9)$ & {$[92.7(2)]$} \\
\hline $\mathrm{N}(6)-\mathrm{Co}(1)-\mathrm{N}(2)$ & $95.5(7)$ & [92.7 (2)] \\
\hline $\mathrm{N}(5)-\mathrm{Co}(1)-\mathrm{N}(2)$ & $175.6(7)$ & [169.5 (2)] \\
\hline N(5)-Co(1)-N(9) & $85.2(1)$ & [92.7 (2)] \\
\hline $\mathrm{N}(1)-\mathrm{Co}(1)-\mathrm{N}(5)$ & $97.5(9)$ & [95.3 (2)] \\
\hline N(5)-Co(1)-N(6) & $80.9(7)$ & {$[80.2(2)]$} \\
\hline $\mathrm{N}(1)-\mathrm{Co}(1)-\mathrm{N}(9)$ & $176.9(9)$ & [169.5 (2)] \\
\hline $\mathrm{N}(1)-\mathrm{Co}(1)-\mathrm{N}(2)$ & $80.0(9)$ & [80.2 (2)] \\
\hline N(2)-Co(1)-N(9) & $97.5(9)$ & {$[95.3(2)]$} \\
\hline N(6)-Co(1)-N(9) & $92.2(8)$ & [92.7 (2)] \\
\hline $\mathrm{N}(9)-\mathrm{Co}(1)-\mathrm{N}(10)$ & $81.6(8)$ & {$[80.2(2)]$} \\
\hline $\mathrm{N}(1)-\mathrm{Co}(1)-\mathrm{N}(10)$ & $96.5(8)$ & [92.7 (2)] \\
\hline $\mathrm{N}(2)-\mathrm{Co}(1)-\mathrm{N}(10)$ & $86.6(8)$ & [92.7 (2)] \\
\hline $\mathrm{N}(6)-\mathrm{Co}(1)-\mathrm{N}(10)$ & $173.7(8)$ & [169.5 (2)] \\
\hline $\mathrm{N}(5)-\mathrm{Co}(1)-\mathrm{N}(10)$ & $97.4(7)$ & [95.3 (2)] \\
\hline
\end{tabular}

*Comparative values in square brackets are from ref. [7]. 
Finally, it should be noted that the title compound, in spite of the fact that it contains an unfamiliar $\left[\mathrm{Co}\left(\mathrm{H}_{2} \mathrm{Oxado}\right)_{3}\right]^{2+}$ ion, happens to be a serendipitous isolation. Therefore, a systematic procedure designed to fabricate this compound is to be applied in our forthcoming works.

\section{Conclusion}

We have isolated from aqueous solution the salt $\left[\mathrm{Co}\left(\mathrm{H}_{2} \mathrm{Oxado}\right)_{3}\right] \mathrm{C}_{2} \mathrm{O}_{4} \cdot \mathrm{H}_{2} \mathrm{Oxado} \cdot 2 \mathrm{H}_{2} \mathrm{O}$ containing the unprecedented tris-chelated $\mathrm{Co}^{\mathrm{II}}$ complex cation, $\left[\mathrm{Co}\left(\mathrm{H}_{2} \mathrm{Oxado}\right)_{3}\right]^{2+}$. In this cation, as well as in the familiar $\left[\mathrm{Co}\left(\mathrm{H}_{2} \mathrm{Oxado}\right)_{3}\right]^{3+}$ ion, the central cobalt atom is in the same pseudo-octahedral coordination geometry of the six imino $\mathrm{N}$ atoms of $\mathrm{H}_{2}$ Oxado. In the crystal, the $\left[\mathrm{Co}\left(\mathrm{H}_{2} \mathrm{Oxado}\right)_{3}\right]^{2+}$ ions are hydrogen-bonded into centrosymmetric dimers, thus generating zig-zag chains running parallel to [001]. It is interesting to note that the dipositive complex cation $\left[\mathrm{Co}\left(\mathrm{H}_{2} \mathrm{Oxado}\right)_{3}\right]^{2+}$ appears as resulting from the reduction of the tripositive complex cation $\left[\mathrm{Co}\left(\mathrm{H}_{2} \mathrm{Oxado}\right)_{3}\right]^{3+}$, a process reminiscent of catalytic or biological reactions involving transfer of electrons.

\section{Acknowledgements}

We thank Professor You Song (Nanjing University, China) and his research team for their help in the X-ray structural analysis.

\section{References}

[1] Coronado, E., Forment-Aliaga, A., Galán-Mascarós, J.R., Giménez-Saiz, C., Gómez-García, C.J., Martinéz-Ferrero, E., Nuez, A. and Romero, F.M. (2003) Multifunctional Molecular Materials. Solid State Sciences, 5, 917-924. http://dx.doi.org/10.1016/S1293-2558(03)00116-X

[2] Bein, T. and Stucky, G.D. (1996) Preface to the Special Issue. Chemistry of Materials, 8, 1569-1570. http://dx.doi.org/10.1021/cm960902s

[3] Moulton, B. and Zaworotko, M.J. (2001) From Molecules to Crystal Engineering: Supramolecular Isomerism and Polymorphism in Network Solids. Chemical Reviews, 101, 1629-1658. http://dx.doi.org/10.1021/cr9900432

[4] Rao, C.N.R. and Nath, M. (2003) Inorganic Nanotubes. Dalton Transactions, No. 1, 1-24. http://dx.doi.org/10.1039/b208990b

[5] Bélombé, M.M., Nenwa, J., Mbiangué, Y.A., Evina-Nnanga, G., Mbomékallé, I.M., Hey-Hawkins, E., Lönnecke, P. and Majoumo, F. (2003) Unusual Aquation of $\mathrm{Ba}^{2+}$ Ions in the Solid State: Synthesis and X-Ray Structural and Spectroscopic Characterization of the Novel Polymeric Complex Salt of Empirical Formula $\left\{\mathrm{Ba}_{6}\left(\mathrm{H}_{2} \mathrm{O}\right)_{17}\left[\mathrm{Cr}(\mathrm{ox})_{3}\right]_{4}\right\} \cdot 7 \mathrm{H}_{2} \mathrm{O}$ (ox = Oxalate Dianion). Dalton Transactions, No. 11, 2117-2118. http://dx.doi.org/10.1039/b302489j

[6] Bekaroglu, Ö., Sarisaban, S., Koray, A.R., Nuber, B., Weidenhammer, K., Weiss, J. and Ziegler, M.L. (1978) The Crystal Structure of Tris(oxamide oxime)cobalt(III) Trichloride, $\left[\mathrm{Co}\left(\mathrm{C}_{2} \mathrm{H}_{6} \mathrm{~N}_{4} \mathrm{O}_{2}\right)_{3}\right] \mathrm{Cl}_{3}$. Acta Crystallographica Section. B, 34, 3591-3593. http://dx.doi.org/10.1107/S0567740878011668

[7] Bélombé, M.M., Jokwi, I., Ngameni, E., Roux, R. and Nuber, B. (1993) Transition Metal Complexes of Oxamide Oxime, 1. Synthesis and X-Ray Crystal Structure of Tris(oxamide oxime- $\mathrm{N}^{1}{ }^{2} \mathrm{~N}^{1}$ )cobalt(III) Triiodide $\left[\mathrm{Co}\left(\mathrm{H}_{2} \mathrm{Oxao}\right)_{3}\right] \mathrm{I}_{3}$. Zeitschrift für Naturforschung Teil B, 48, 1719-1722.

[8] Bélombé, M.M., Nenwa, J., Bebga, G., Fokwa, B.P.T. and Dronskowski, R. (2007) Bis[tris(oxamide dioxime- $\kappa^{2} N, N$ ) cobalt(III)] Oxalate bis(sulfate) Dodecahydrate. Acta Crystallographica Section E, 63, m2037-m2038. http://dx.doi.org/10.1107/S1600536807031169

[9] Bélombé, M.M., Nenwa, J., Mbiangué, Y.A., Majoumo, F., Lönnecke, P. and Hey-Hawkins, E. (2009) Hydrogen Bonded Pillars of Alternating Chiral Complex Cations and Anions: 1. Synthesis, Characterization, X-Ray Structure and Thermal Stability of catena- $\left\{\left[\mathrm{Co}\left(\mathrm{H}_{2} \text { oxado }\right)_{3}\right]\left[\mathrm{Cr}\left(\mathrm{C}_{2} \mathrm{O}_{4}\right)_{3}\right] \cdot 5 \mathrm{H}_{2} \mathrm{O}\right\}$ and of its Precursor $\left(\mathrm{H}_{3} \mathrm{Oxado}\right)-\left[\mathrm{Co}\left(\mathrm{H}_{2} \mathrm{Oxado}\right)_{3}\right]$ $\left(\mathrm{SO}_{4}\right)_{2} \cdot 2 \mathrm{H}_{2} \mathrm{O}$. Dalton Transactions, No. 23, 4519-4525. http://dx.doi.org/10.1039/b818793b

[10] Mbiangué, Y.A., Nenwa, J., Bélombé, M.M., Ngoune, J. and Álvarez, E. (2012) Hydrogen-Bonded Pillars of Alternating Chiral Complex Cations and Anions: 2. Synthesis, Characterization and X-Ray Structure of Isomorphous catena$\left\{\left(\mathrm{H}_{3} \mathrm{O}\right)\left[\mathrm{K}\left(\mathrm{H}_{2} \mathrm{O}\right)_{3}\right] @\left[\mathrm{Ni}\left(\mathrm{H}_{2} \mathrm{Oxado}\right)_{3}\right]_{2}\left[\mathrm{Cr}\left(\mathrm{C}_{2} \mathrm{O}_{4}\right)_{3}\right]_{2} \cdot 3 \mathrm{H}_{2} \mathrm{O}\right\} \quad$ and catena- $\left\{\left(\mathrm{H}_{3} \mathrm{O}\right)\left[\mathrm{Li}\left(\mathrm{H}_{2} \mathrm{O}\right)_{3}\right] @\left[\mathrm{Ni}\left(\mathrm{H}_{2} \mathrm{Oxado}\right)_{3}\right]_{2}\right.$ $\left.\left[\mathrm{Cr}\left(\mathrm{C}_{2} \mathrm{O}_{4}\right)_{3}\right]_{2} \cdot 3 \mathrm{H}_{2} \mathrm{O}\right\}$. Science Jet, 1, 1-9.

[11] Ephraim, J. (1889) Zur Kenntniss des Rubeanwasserstoffs. Berichte der Deutschen Chemischen Gesellschaft, 22, 2305-2306. http://dx.doi.org/10.1002/cber.188902202108

[12] Bailar, J.C. and Jones, E.M. (1939) Tris(oxalato) Salts. Inorganic Syntheses, 1, 35-38. http://dx.doi.org/10.1002/9780470132326.ch13 
[13] (2003) SMART \& SAINT Software Reference Manual, Version 6.45. Bruker Analytical X-Ray Systems, Inc., Madison.

[14] Sheldrick, G.M., SADABS, Version 2.05 (2002) A Software for Empirical Absorption Correction. University of Göttingen, Göttingen.

[15] Sheldrick, G.M., SHELXL97 (1997) Program for Crystal Structure Refinement. University of Göttingen, Göttingen.

[16] Endres, H., Genc, N. and Nöthe, D. (1983) The Catena Structure and EPR Properties of Bis(oxamide oximato)copper(II) Oxamide oxime, $\left[\mathrm{Cu}\left(\mathrm{C}_{2} \mathrm{H}_{5} \mathrm{~N}_{4} \mathrm{O}_{2}\right)_{2}\right] \cdot \mathrm{C}_{2} \mathrm{H}_{6} \mathrm{~N}_{4} \mathrm{O}_{2}$. Acta Crystallographica Section C, 39, 701-703.

http://dx.doi.org/10.1107/s0108270183005971

\section{Appendix A. Supplementary Material}

Detailed crystallographic data in CIF format for this paper were deposited with the Cambridge Crystallographic Data Centre (CCDC-839359). The data can be obtained free of charge at

www.ccdc.cam.ac.uk/conts/retrieving.html [or from Cambridge Crystallographic Data Centre (CCDC), 12 Union Road, Cambridge CB2 IEZ, UK; fax: +44 (0) 1223-336033; e-mail: deposit@ccdc.cam.ac.uk]. 